\title{
Effect of agronomic biofortification on growth, yield, uptake and quality characters of maize (Zea mays .L) through integrated management practices under North-eastern region of Tamil Nadu, India
}

\author{
Augustine R.* \\ Department of Agronomy, Faculty of Agriculture, Annamalai University, Chidambaram-608002 \\ (Tamil Nadu) India \\ D. Kalyanasundaram \\ Department of Agronomy, Faculty of Agriculture, Annamalai University, Chidambaram-608002 \\ (Tamil Nadu) India \\ ${ }^{*}$ Corresponding author. Email: augustinerajendran@gmail.com
}

\section{Article Info}

https://doi.org/10.31018/ jans.v13i1.2539 Received: February 2, 2021

Revised: March 6, 2021

Accepted: March 10, 2021

\section{How to Cite}

R. Augustine and Kalyanasundaram, D. (2021). Effect of agronomic biofortification on growth, yield, uptake and quality characters of maize (Zea mays .L) through integrated management practices under North-eastern region of Tamil Nadu, India. Journal of Applied and Natural Science, 13(1): 278 - 286. https://doi.org/10.31018/jans.v13i1.2539

\begin{abstract}
Agronomic biofortification increases the concentration of target mineral in edible portions of crops by the use of mineral fertilizers to increase dietary intake of target minerals. Among these iron and zinc deficiencies in human nutrition are noticed in $\infty u n-$ tries where maize is the staple food. The objective of this study was to evaluate agronomic biofortification performance in association with Integrated Nutrient Management in maize (Zea mays .L). The study was conducted under field conditions in Chinnakandiankuppam village, Vriddhachalam Taluk, in the North-eastern region of Tamil Nadu state, India of Kharif 2020 season. Two hybrids in main plots $\left(\mathrm{M}_{1}-\right.$ Non biofortified and $\mathrm{M}_{2}$ - Biofortified) were combined with six treatments in sub-plots (100\% RDF through NPK $\left(\mathrm{S}_{1}\right), 100 \%$ RDF through FYM $\left(\mathrm{S}_{2}\right), 50 \%$ RDF through NPK $+50 \%$ through FYM $\left(\mathrm{S}_{3}\right)$ as soil application, $\mathrm{S}_{1}+$ Zinc + Iron $\left(S_{4}\right), S_{2}+$ Zinc + Iron $\left(S_{5}\right)$ and $S_{3}+$ Zinc + Iron $\left(S_{6}\right)$ as foliar application with evaluations were carried out in wet season period of the year. Application of 50 per cent RDF through NPK +50 per cent RDF through FYM with Fe, Zn, foliar applications $\left(\mathrm{S}_{6}\right)$ was the most efficient agronomic biofortification practice for growth attributes, yield and yield attributes, nutrient uptake and quality parameters for the maize cropping system under irrigated condition of north eastern zone of Tamilnadu State, India.
\end{abstract}

Keywords: Biofortification, Foliar, Iron, Nutrition, Zinc

\section{INTRODUCTION}

Unlike various other high value crops, the direct involvement of small and marginal farmers is very intense in the cultivation of maize. There is immense potential in the Indian Agribusiness ecosystem because of its value of output and degree of involvement of maize growers. Due to recent research advancements, the quality protein maize, single cross and 3-way cross hybrids have given a fillip to the nutritional quality of this cereal (NCoMM Special report, 2017). Indian maize production depends heavily on the Southwest monsoon as more than three-fourth of the maize is produced in the Kharif season. Maize is the third largest food grain crop next to wheat and rice, occupying 9.21 million hec- tares in India with a total production of 25.13 million tonnes and productivity of $6555 \mathrm{~kg} \mathrm{ha}^{-1}$ for both kharif and rabi seasons. In Tamilnadu (2018-19), maize occupies an area of 0.38 million ha with a production of 2.51 million tonnes and productivity of $6.55 \mathrm{~T} \mathrm{ha}^{-1}$ (Agricultural statistics at a glance, 2019).

In general, human population suffers from micronutrient deficiencies, which occurs due to inadequate intake of essential micronutrients in daily diet. To combat these deficiencies, the biofortification process through agronomic practices offers a sustainable solution, a shortterm approach and the easiest way of availability in the diet through the edible parts (Roman et al., 2019).Although simple and inexpensive, the application of fertilizers containing essential mineral micronutrients 
is complicated by several factors, such as the application method, soil compaction, mineral mobility in the plant and its accumulation site (Zhu et al., 2007). The bioavailability of micronutrients from soil to crop is influenced by many factors (i.e. $\mathrm{pH}$, organic matter content, soil aeration and moisture and interactions with other elements) and by the crop variety that defines the structure and functioning of rooting systems (Alloway, 2009). Some plants can modify the rhizosphere by the excretion of $\mathrm{H}+$ ions or organic acids that enhance micronutrient availability and uptake (Zhang et al., 2010; Marschner and Zed, 2012).

Due to its improved nutrient uptake and micronutrient availability in the edible plant parts, foliar fertilization was found superior to soil application (Lawson et al., 2015). The combination of soil and foliar application is often the most effective method (Phattarakul et al., 2012 and Cakmak et al., 2010). To avoid immobilization in the soil, foliar pathways were generally found more effective in ensuring nutrient uptake besides its costliness (Garcia-Bauelos et al., 2014).

Singh et al., (1995) reported that, $\mathrm{Zn}$ and Fe are part of the photosynthesis, assimilation and translocation of photosynthates from source (leaves) to sink (cob). Due to foliar application of $\mathrm{Fe}$ and $\mathrm{Zn}$, significant increase in growth (plant height, leaf area, dry matter production) and yield attributes were recorded (Nikhil and Salakinkop, 2018). Similar results were obtained by Hythum and Nasser (2012) in maize (Zea mays. L.) crop.

The effectiveness of agronomic biofortification lies with the interaction effects of both micronutrients with macronutrients. Both $\mathrm{Fe}$ and $\mathrm{Zn}$ interact positively with $\mathrm{N}$ and inversely with $\mathrm{P}$. A positive $\mathrm{N} \times \mathrm{Zn}$ interaction in cereals was reported by a number of researchers (Lakshmanan et al., 2005; Pooniya and Shivay, 2013). There is a positive correlation between increased micronutrient ( $\mathrm{Fe}$ and $\mathrm{Zn}$ ) uptake and concentration in the edible parts of the crops (grains) due to high $\mathrm{N}$ application (Kutman et al., 2011a,b; Shi et al., 2010; Cakmak et al., 2010 and White and Broadley, 2011; Lakshmanan et al., 2005; Pooniya and Shivay, 2013).

Interestingly, increased $\mathrm{Zn}$ concentration in maize kernels is positively correlated with grain yield, 1000-grain weight, cob diameter and cob length (Shivay and Prasad, 2012; Mohsin et al., 2014 and Yashbir and Rajendra, 2014). Yuan et al. (2012) found improvement in grain yield, protein content and total amino acid content as the result of $\mathrm{Fe}$ and $\mathrm{Zn}$ spraying.

The timing of foliar application is an important factor determining its effectiveness in increasing $\mathrm{Fe}$ and $\mathrm{Zn}$ concentration. Foliar application of $\mathrm{FeSO}_{4}$ has been a little more effective than soil application at increasing grain Fe concentration in cereals and can increase the yield of crops growing on soils with low Fe availability (Shahzad et al., 2014).
The $\mathrm{Zn}$ foliar application done at late growth or reproductive stage have improved $\mathrm{Zn}$ content in grains (Ozturk et al., 2006; Yilmaz et al., 2007; Cakmak, 2008 and Zhang et al., 2010). Both kernel Fe and Zn concentration have a positive correlation with grain yield (Chakraborti et al., 2009; Cakmak et al., 2010; Saleem et al., 2016 and Roman Nissar et al., 2019). Thus, the present study was formulated to study the effect of agronomic biofortification on maize (Zea mays. L.) growth, yield and quality characters through integrated nutrient management practices in North-eastern agroclimatic zone of Tamilnadu under the semi-arid tropic region of India.

\section{MATERIALS AND METHODS}

\section{Experimental site description}

The investigation was carried out in July-2020 during kharif season at the Chinnakandiankuppam village, Vriddhachalam Taluk, Tamilnadu state to study the Effect of Agronomic biofortification on growth, yield, uptake and quality characters of maize through integrated management practices under North-eastern region of Tamil Nadu. The experiment site was geographically located in North Eastern agro-climatic zone of Tamilnadu and is delineated under semi-arid tropic of India. It lies between $11.3^{\circ} \mathrm{N}, 79.26^{\circ} \mathrm{E}$ longitude at an altitude of 42.67 meters above mean sea level. The mean annual rainfall of Vriddhachalam was $403.22 \mathrm{~mm}$ during the southwest monsoon and $580.50 \mathrm{~mm}$ during northeast monsoon and the mean maximum and minimum temperatures were $27-42^{\circ} \mathrm{C}$ and $19-24^{\circ} \mathrm{C}$ respectively. The Relative Humidity ranges between $65 \%$ $-85 \%$.

The pre-sowing soil samples collected from each treatment plots of the experimental field in three replicates were analysed for the initial physico-chemical properties. The soil of the experimental field was clay loam in texture belonging to Gadillum series, classified taxonomically as Typic Ustropepts. Maize hybrid, VH133545 (QPM biofortified) and NK 6668 (Nonbiofortified) were used for trials during kharif 2020 seasons, respectively.

\section{Field experiment details}

The field experiment was laid out in split-plot design, and sampling was done in three replicates with 36 plots in total, each covering $20 \mathrm{~m}^{2}(5 \mathrm{~m} \times 4 \mathrm{~m})$. The experiment was conducted during 2020 kharif season (JulyOctober) with two hybrids $\left(\mathrm{M}_{1}\right.$ - Non biofortified hybrid and $\mathrm{M}_{2}-\mathrm{QPM}$ biofortified hybrid) as main plots and six nutrient level treatments as sub-plots viz., Soil Application $-\mathrm{S}_{1}-100 \%$ RDF through NPK, $\mathrm{S}_{2}-100 \% \mathrm{RDF}$ through FYM, $S_{3}-50 \%$ RDF through NPK $+50 \%$ through FYM and Foliar Application $-\mathrm{S}_{4}-\mathrm{S}_{1}+$ Zinc + Iron, $\mathrm{S}_{5}-\mathrm{S}_{2}+$ Zinc + Iron, $\mathrm{S}_{6}-\mathrm{S}_{3}+$ Zinc + Iron. For the 
present study, the soil samples were collected from thirty six plots. Each plot in the experimental field was ploughed once with tractor-mounted mouldboard plough and the field was harrowed and levelled to fine tilth without disturbing the layout for next season. After ploughing, bunds and irrigation channels of each plot were rectified. All the cultural practices and plant protection measures for maize were followed as per the recommendations of the crop production guide of Agricultural crops in Tamilnadu.

\section{Soil application (Manure and fertilizer)}

Well decomposed FYM were used as organic sources for nitrogen. The required quantities of organic manures were incorporated in the soil 10 days before puddling. The recommended dose of NPK 250:75:75 kg/ha in the form of urea $(46 \% \mathrm{~N})$, single super phosphate $\left(16 \% \mathrm{P}_{2} \mathrm{O}_{5}\right)$ and muriate of potash $\left(60 \% \mathrm{~K}_{2} 0\right)$ were applied as per the treatment. Of this, 50 per cent $\mathrm{N}$ and full dose of $\mathrm{P}_{2} \mathrm{O}_{5}$ and $\mathrm{K}_{2} \mathrm{O}$ were applied as basal. The remaining 50 per cent $\mathrm{N}$ was applied in two splits at 25 days after sowing (DAS) and 45 DAS.

\section{Foliar application (Iron and Zinc)}

Foliar application of 0.5 per cent $\mathrm{FeSo}_{4}$ and $\mathrm{ZnSo}_{4}$ as per treatments was done twice at 30 and 60 DAS, respectively.

\section{Seeds and sowing}

Seeds of Biofortified (QPM) and non biofortified (commercial) maize hybrid VH133545 and NK 6668 were used for the study. Seeds were pre-treated with Azospirillum and pseudomonas and were sown on the side of the ridges. Seeds were dibbled at the rate of one seed hill ${ }^{-1}$ with a spacing of $60 \times 25 \mathrm{~cm}$. Recommended agronomic practices and plant protection measures were followed. Gap filling was done 7 DAS and thinning 15 DAS to maintain one healthy plant hill ${ }^{-1}$. Two hand weedings were done to manage the weeds. The first hand weeding was given on 20 DAS and the other at 40 DAS.

\section{Sampling procedures and measurements}

The collected soil samples were analyzed for $\mathrm{pH}$, EC and available macro nutrients. Standard procedures were adopted for analysis of the nutrients in the laboratory. Ten plants from each net plot area were tagged and used for recording all biometric observations for growth attributes (plant height, leaf area Index, dry matter production, days taken to $50 \%$ tasseling and silking), yield and yield attributes (cob length, cob girth, cob weight, no. of grains per row of cob, no. of grain rows per cob, thousand grain weight, grain yield and stover yield), nutrient uptake (N, P and $\mathrm{K}$ ) and quality parameter (crude protein, starch, iron and zinc) were recorded at harvest.

\section{Statistical analysis}

The data obtained from various observations was statistically analyzed as the split plot design procedure using the standard techniques of Analysis of Variance (ANOVA) as suggested by Gomez and Gomez (1984). The critical difference at $5 \%$ level of probability was calculated for testing the significance of the difference between any two means wherever ' $F$ ' test was found significant. Wherever the calculated 'F-value' exceeded the tabulated value, the difference between the treatments was significant.

\section{RESULTS AND DISCUSSION}

\section{Growth and attributes}

The effect of agronomic biofortification in maize through integrated management practices on plant height, leaf area index, dry matter production and days to $50 \%$ flowering is presented in Table 1 . It is obvious that with an integrated nutrient dose of fertilizers and micronutrient foliar application, any crop would perform at its best, because of adequate and balanced nutrient supply to the crop at the right time of crop requirement. Accordingly, the maize crop under adequate and comfortable nutrition produced the growth parameters of the highest stature.

\section{Plant height (cm)}

The plant height differed significantly $(P \leq 0.05)$ due to integrated nutrient with foliar applications. The highest plant height at 90 DAS $(208.25 \mathrm{~cm})$ was recorded in $\mathrm{S}_{6}$ -50 per cent RDF through NPK and 50 per cent RDF through FYM with Fe, Zn foliar application, followed by $\mathrm{S}_{4}(204.00 \mathrm{~cm})-100$ per cent RDF through NPK with Iron + Zinc foliar applications under different nutrient levels. This was followed by $S_{1}(202 \mathrm{~cm})-100$ per cent RDF through NPK and $S_{3}(201.00 \mathrm{~cm})-50 \%$ RDF through NPK $+50 \%$ RDF through FYM nutrient level treatments. Increase in plant height was due to the slow and steady release of nutrients which perhaps enables the crop growth towards the reproductive stage. Increased plant height is due to increased uptake of $\mathrm{N}$ which being the constituent of protein and protoplasm, vigorously induced the vegetative development of the plants. Plant height was positively correlated and significantly associated with grain yield per plant. Similar results were reported by Rahman et al. (2013). The combined source of fertilizers, initially to get decomposed and mineralize before making available to plants, thus causes nutrients to be slowly released to crop (Okoroafor et al., 2013). Priya et al. (2014) recorded that plant height and number of leaves was maximum due to application of $100 \%$ NPK fertilizers with $10 \mathrm{t} \mathrm{ha}^{-1}$ FYM. The above findings were similar with Ravi et al., (2012) and Zerihun et al. (2013). Sindhi et al., (2018) reported that combined application of or- 
Table 1. Effect of agronomic biofortification through integrated nutrient management practices on growth attributes of Zea mays.

\begin{tabular}{|c|c|c|c|c|c|}
\hline \multirow{2}{*}{$\begin{array}{l}\text { Treatments } \\
\text { (Main plots - M ; Sub plots - S) }\end{array}$} & \multicolumn{3}{|c|}{90 Days after sowing (DAS) } & \multicolumn{2}{|c|}{ Days taken for $\mathbf{5 0 \%}$ flowering } \\
\hline & $\mathrm{PH}(\mathrm{cm})$ & LAI & $\begin{array}{l}\text { DMP (Kg } \\
\text { ha }^{-1} \text { ) }\end{array}$ & $\begin{array}{l}\text { Days taken for } \\
50 \% \text { tasseling }\end{array}$ & $\begin{array}{l}\text { Days taken for } \\
50 \% \text { Silking }\end{array}$ \\
\hline \multicolumn{6}{|l|}{ Hybrid } \\
\hline$M_{1}-$ Non biofortified & 198.25 & 3.92 & 12839.17 & 55.22 & 60.98 \\
\hline$M_{2}-$ Biofortified & 194.17 & 3.75 & 12640.33 & 54.35 & 60.48 \\
\hline SEd & 0.29 & 0.12 & 3.00 & 0.30 & 0.23 \\
\hline$C D(p=0.05)$ & 1.24 & NS & 12.91 & 1.29 & NS \\
\hline \multicolumn{6}{|l|}{ Nutrient levels } \\
\hline $\mathrm{S}_{1-}-100 \%$ RDF through NPK & 202.00 & 4.13 & 12825.00 & 55.25 & 61.47 \\
\hline $\mathrm{S}_{2}-100 \%$ RDF through FYM & 178.00 & 3.25 & 12315.00 & 53.15 & 58.42 \\
\hline $\mathrm{S}_{3}-50 \%$ through NPK $+50 \%$ through FYM & 201.00 & 3.90 & 12811.00 & 54.55 & 60.57 \\
\hline $\mathrm{S}_{4}-\mathrm{S} 1+$ Zinc and Iron as foliar application & 204.00 & 4.16 & 12920.00 & 55.85 & 61.92 \\
\hline $\mathrm{S}_{5}-\mathrm{S} 2+$ Zinc and Iron as foliar application & 184.00 & 3.31 & 12537.50 & 53.50 & 59.40 \\
\hline $\mathrm{S}_{6}-\mathrm{S} 3+$ Zinc and Iron as foliar application & 208.25 & 4.29 & 13030.00 & 56.40 & 62.62 \\
\hline SEd & 0.17 & 0.05 & 1.73 & 0.17 & 0.05 \\
\hline$C D(p=0.05)$ & 0.35 & 0.10 & 3.61 & 0.36 & 0.11 \\
\hline \multicolumn{6}{|l|}{ Interaction } \\
\hline $\mathrm{M}_{1} \times \mathrm{S}_{1}$ & 203.00 & 4.25 & 12930.00 & 55.80 & 61.90 \\
\hline $\mathrm{M}_{1} \times \mathrm{S}_{2}$ & 182.00 & 3.25 & 12305.00 & 53.60 & 58.50 \\
\hline $\mathrm{M}_{1} \times \mathrm{S}_{3}$ & 202.00 & 4.27 & 12915.00 & 55.60 & 60.70 \\
\hline $\mathrm{M}_{1} \times \mathrm{S}_{4}$ & 206.00 & 4.10 & 13010.00 & 55.90 & 62.20 \\
\hline $\mathrm{M}_{1} \times \mathrm{S}_{5}$ & 185.00 & 3.32 & 12725.00 & 54.00 & 59.47 \\
\hline $\mathrm{M}_{1} \times \mathrm{S}_{6}$ & 211.50 & 4.35 & 13150.00 & 56.40 & 63.10 \\
\hline$M_{2} \times S_{1}$ & 201.00 & 4.01 & 12720.00 & 54.70 & 61.03 \\
\hline $\mathrm{M}_{2} \times \mathrm{S}_{2}$ & 174.00 & 3.25 & 12325.00 & 52.70 & 58.33 \\
\hline $\mathrm{M}_{2} \times \mathrm{S}_{3}$ & 200.00 & 3.70 & 12707.00 & 53.50 & 60.43 \\
\hline $\mathrm{M}_{2} \times \mathrm{S}_{4}$ & 202.00 & 4.05 & 12830.00 & 55.80 & 61.63 \\
\hline $\mathrm{M}_{2} \times \mathrm{S}_{5}$ & 183.00 & 3.29 & 12350.00 & 53.00 & 59.33 \\
\hline $\mathrm{M}_{2} \times \mathrm{S}_{6}$ & 205.00 & 4.22 & 12910.00 & 56.40 & 62.13 \\
\hline \multicolumn{6}{|l|}{$\mathrm{M} \times \mathrm{S}$} \\
\hline SEd & 0.11 & 0.03 & 1.17 & 0.12 & 0.04 \\
\hline$C D(p=0.05)$ & 0.28 & 0.09 & 2.88 & 0.29 & 0.14 \\
\hline \multicolumn{6}{|l|}{$\mathrm{S} \times \mathrm{M}$} \\
\hline SEd & 0.12 & 0.03 & 1.22 & 0.12 & 0.04 \\
\hline$C D(p=0.05)$ & 0.25 & 0.07 & 2.55 & 0.26 & 0.08 \\
\hline
\end{tabular}

Where $\mathrm{PH}=$ plant height, $\mathrm{LAI}=$ leaf area index, $\mathrm{DMP}=$ dry matter production

ganic and inorganic fertilizer have achieved a significant plant growth, yield, quality and nutrient uptake. Similar findings were reported by Binoy and Sinha, (2017) that the combined treatments with $75 \%$ RDF + PSB + Azotobacter + vermicompost @ 5.0 t/ha were significant, compared to other treatments on maize at Cooch Behar, West Bengal.

\section{Leaf area index}

Leaf area Index (LAI) is an indicator of photosynthesis and its translocation. Significant increase in LAl at 90 DAS (4.29) was recorded in $S_{6}$, followed by $S_{4}(4.16)$ under different nutrient levels, which was on par with $\mathrm{S}_{1}$ (4.13) and $S_{3}$ (3.90) nutrient level treatments. In the present study, better utilization of $\mathrm{N}$ resulted in higher leaf surface area and thereby higher LAl. This is in accordance with earlier findings of Agyenium et al., (2006).

\section{Dry matter production}

The higher DMP was significantly $(P \leq 0.05)$ higher in the nutrient level (sub-plot) treatment $S_{6}\left(13030 \mathrm{~kg} \mathrm{ha}^{-1}\right)$ compared to $S_{4}\left(12920 \mathrm{~kg} \mathrm{ha}^{-1}\right)$. This was followed by nutrient level (sub-plot) treatment receiving $S_{1}$ (12825 
$\mathrm{kg} \mathrm{ha}^{-1}$ ) and $\mathrm{S}_{3}\left(12811 \mathrm{~kg} \mathrm{ha}^{-1}\right)$. Amanullah (1997) reported that INM with micronutrient foliar spray enabled the leaf area duration to extend and provided an opportunity for the plants to increase the photosynthetic rate leading to the higher accumulation of dry matter. Leaf area index and dry matter were significantly correlated demonstrating that, higher amount of radiation associated with higher LAI contribute to enhanced dry matter production (Kolawole and Samson, 2009).

\section{Days to $\mathbf{5 0 \%}$ flowering}

Increase in days to $50 \%$ tasseling and $50 \%$ silking was higher under $S_{6}(56.40$ and 62.62$)$ followed by $S_{4}$ (55.85 and 61.92) under nutrient (sub-plot) treatments, respectively. This treatment was on par with $S_{1}(55.25$ and 61.47) and $S_{3}(54.55$ and 60.57). Amanat (1998), Farooqui (1999) and Tasneem Khaliq et al. (2004) observed that the availability of nitrogen and phosphorus at adequate quantity delays the tasseling period. Ayoola and Makinde (2009) reported that combined organic and inorganic source with micronutrient applications prolonged the vegetative phase of the plants leading to longer duration and ensuring higher yield.

\section{Yield and yield attributes}

The effect of agronomic biofortification in maize through integrated management practices on cob length, cob girth, cob weight, no. of grains per row of cob, no. of grain rows per cob, thousand-grain weight are presented in Fig. 1 and grain and stover yield recorded at harvest are presented in Fig. 2 respectively. The yield attributes were highly significant $(P \leq 0.05)$ for a different combination of nutrient levels in sub-plots. Among the treatments, the highest cob length (18.18 $\mathrm{cm})$, cob girth $(15.25 \mathrm{~cm})$, No. of grains row $^{-1}(35.05)$ and No. of rows $\mathrm{cob}^{-1}$ (15.02) was recorded in $S_{6}-50$ per cent RDF through NPK and 50 per cent RDF through FYM with $\mathrm{Fe}, \mathrm{Zn}$ foliar application. The cob length, cob girth, no. of grains row ${ }^{-1}$ and no. of rows cob ${ }^{-1}$ receiving inorganic fertilizer integrated with organic sources and the foliar application was on par with each other but was significantly higher than $S_{2}-100$ per cent RDF through FYM only treatment. Significant higher growth (plant height and leaf area) and yield and its parameters (number of grains per cob, cobs weight per plant, Test weight and Stover yield) were recorded with INM than 100\% RDF alone (Auwal and Amit, 2017). It was also observed by Tetarwal et al. (2011) and Verma et al. (2012). Karan et al. (2018) recorded that integrated organics and inorganics application to maize significantly improved the growth, yield attributes, grain and stover yield of maize at par with $100 \%$ inorganics. Rajesh Ranjan et al. (2018) reported that FYM combined $25 \%$ reduced inorganic have significantly increased the yield and yield attributes of maize. Nikhil and Salakinkop (2018) reported that growth (plant height, leaf area, dry matter production) and yield attributes were increased significantly by $\mathrm{Zn}$ and $\mathrm{Fe}$ foliar application and similar findings by Hythum and Nasser (2012) who reported that the foliar spraying of $\mathrm{Zn}+\mathrm{Mn}+\mathrm{Fe}$ gave the highest values of ears/plant, grains/ear, 100-grain weight and grain yield in both 2007 and 2008 seasons in maize grown under clayey soil in Egypt and also by Kalyanasundaram and Augustine (2020a) that Integrated nutrient management (RDF+ soil application of Beema green granules) with foliar application had shown a higher values in yield and yield attributing characters viz., grain weight/cob, number of grain/cob and test weight in hybrid maize ( $Z$. mays L.).

The data on grain yield and stover yield showed that significantly higher grain yield $\left(8349.36 \mathrm{~kg} \mathrm{ha}^{-1}\right)$ and stover yield $\left(10418.67 \mathrm{~kg} \mathrm{ha}^{-1}\right)$ was recorded in the $\mathrm{S}_{6}$ 50 per cent RDF through NPK and 50 per cent RDF through FYM with $\mathrm{Fe}, \mathrm{Zn}$ foliar application followed by $S_{4}-100$ per cent RDF through NPK with Iron + Zinc foliar applications (grain yield $-8273.29 \mathrm{~kg} \mathrm{ha}^{-1}$ and stover yield - $10414.17 \mathrm{~kg} \mathrm{ha}^{-1}$ ) compared to $S_{2}-100$ per cent RDF through FYM (grain yield $-8002.26 \mathrm{~kg}$ ha ${ }^{-1}$ and stover yield $\left.-10310.00 \mathrm{~kg} \mathrm{ha}^{-1}\right)$. Higher yields in the integrated nutrient treatment receiving foliar applications might be due to increased availability of nutrients and the presence of $\mathrm{Fe}$ and Zinc, etc. This increase might be due to the balanced availability of nutrients to assimilate sufficient photosynthates for dry matter production by conversion of the source to sink, reflecting in the form of higher cob length, grain yield, stover yield.

Shinde et al., (2014) recorded the highest cobs/plant, 1000 grain weight, grain yield and straw yield of maize were recorded with $100 \%$ RDF +10 t FYM/ha. Similar findings were concluded by Pandey and Avasthi (2014). A similar observation was recorded by Auwal and Amit (2017) for 50\% RDF along with either 5 t/ha FYM or pressmud and Karan et al., (2018) for $25 \% \mathrm{~N}$ through fortified vermicompost $+75 \% \mathrm{~N}$ through inorganic fertilizer. In one of the earlier study, foliar application of $\mathrm{Fe}_{2} \mathrm{SO}_{4}$ and $\mathrm{ZnSO}_{4}$ has shown increased concentration in cereals (grain), which also enhances yield of crops (Augustine and Kalyanasundaram, 2020a). Increasing the concentration of Iron and Zinc in cereal crops of plant parts was achieved by agronomic biofortification by spraying at the later crop stage or early milking stage. It is predominantly efficient when $\mathrm{Zn}$ foliar applications were tried, shows a yield increase and $\mathrm{Zn}$ content in maize grain during harvest (Augustine and Kalyanasundaram, 2020b).

\section{Nutrient uptake}

The effect of agronomic biofortification in maize through integrated management practices on Nitrogen $(\mathrm{N})$, Phosphorus $(\mathrm{P})$ and Potassium $(\mathrm{K})$ uptake recorded at 


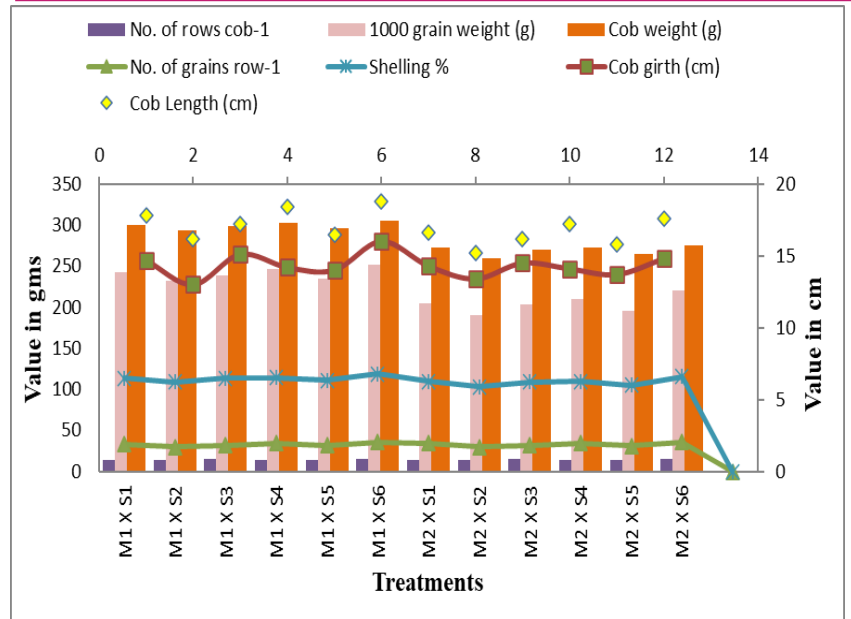

Fig. 1. Effect of agronomic biofortification in maize through integrated nutrient management practices on yield attributes.

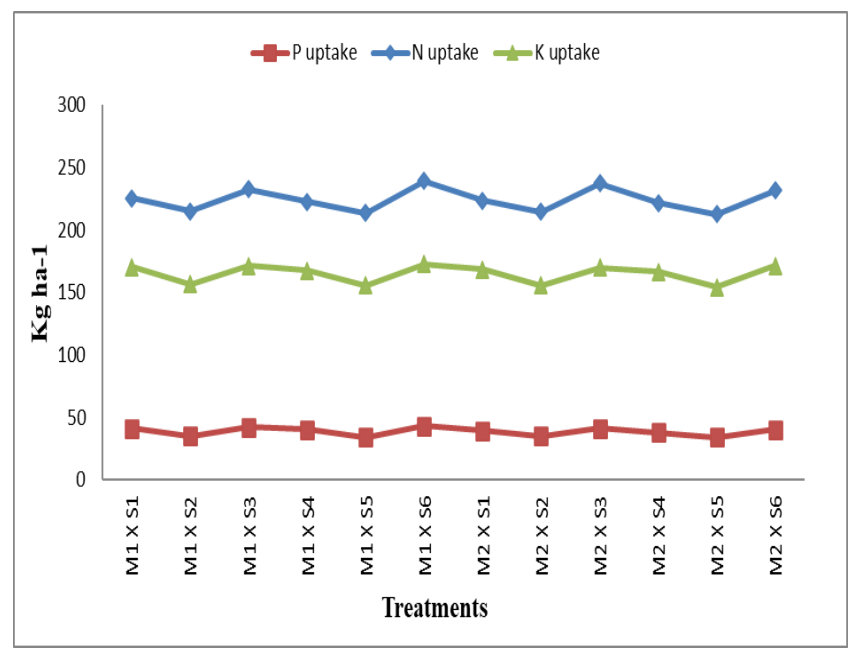

Fig. 3. Effect of agronomic biofortification in maize through integrated nutrient management practices on nutrient uptake.

90 DAS during kharif season of 2020 are presented in Fig 3.

The $\mathrm{N}$ and $\mathrm{K}$ were significantly $(\mathrm{P} \leq 0.05)$ influenced by $\mathrm{S}_{6}-50$ per cent RDF through NPK and 50 per cent RDF through FYM with Fe, Zn foliar application (235.03, 41.15 and $171.93 \mathrm{~kg} \mathrm{ha}^{-1}$ ) and $P$ was significantly influenced by $S_{4}-100$ per cent RDF through NPK with Iron + Zinc foliar applications (41.37 kg ha-1) at 90 DAS followed by $\mathrm{N}$ and $\mathrm{K}$ uptake by $\mathrm{S}_{4}(234.75$ and 170.35 $\left.\mathrm{kg} \mathrm{ha}^{-1}\right)$ and $\mathrm{P}$ uptake by $S_{6}\left(41.15 \mathrm{~kg} \mathrm{ha}^{-1}\right)$. More nutrient uptake and presence of efficient minerals in edible portion happens better with foliar fertilization rather than soil fertilization. (Lawson et al., 2015). Both Fe and $\mathrm{Zn}$ interact positively with $\mathrm{N}$ and inversely with $P$. Similar findings were also reported by Pooniya and Shivay (2013) with $0.2 \% \mathrm{ZnSo}_{4}$ foliar application recorded highest $\mathrm{N}, \mathrm{K}$ and $\mathrm{Fe}$ in basmati rice. Integrated nutrient management (RDF+ soil application of Beema green granules) with foliar application have shown

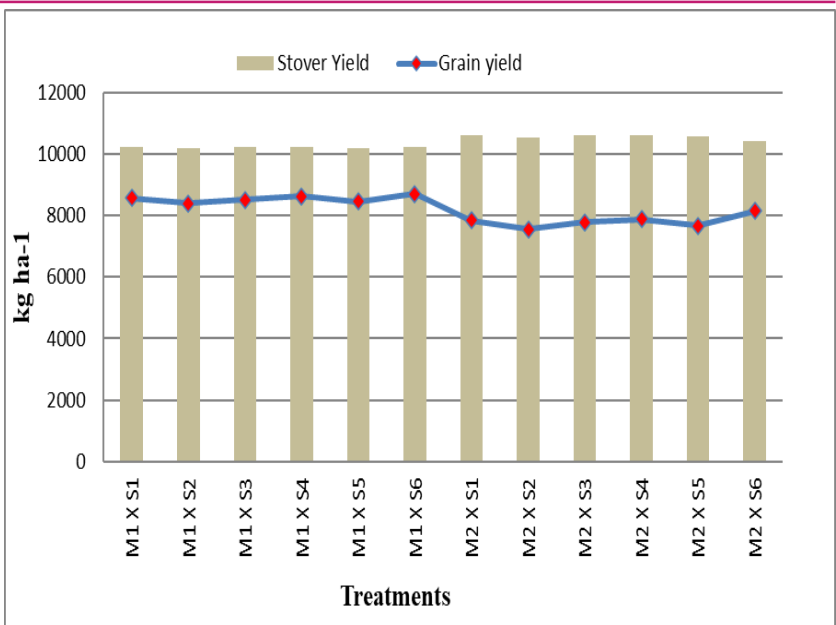

Fig. 2. Effect of agronomic biofortification in maize through integrated nutrient management practices on yield.

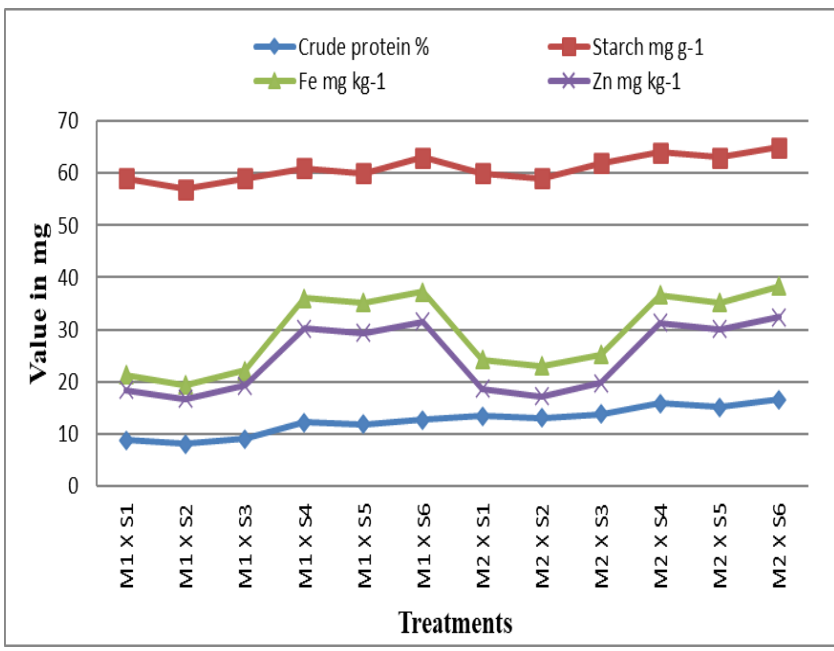

Fig. 4. Effect of agronomic biofortification in maize through integrated nutrient management practices on quality parameters.

improved nutrient uptake in hybrid maize (Zea mays L.) by Kalyanasundaram et al. (2020).

\section{Quality parameters}

The effect of agronomic biofortification in maize through integrated management practices on crude protein, starch, iron (Fe) and zinc ( $\mathrm{Zn})$ are presented in Fig. 4.

Data revealed that under sub-plots (nutrient levels), $S_{6}$ 50 per cent RDF through NPK and 50 per cent RDF through FYM with $\mathrm{Fe}, \mathrm{Zn}$ foliar application was found to be efficient in providing crude protein (14.65\%), starch $\left(63.85 \mathrm{mg} \mathrm{g}^{-1}\right)$, Fe (37.80 $\left.\mathrm{mg} \mathrm{kg}^{-1}\right)$ and $\mathrm{Zn}(31.88 \mathrm{mg} \mathrm{kg}$ $\left.{ }^{-1}\right)$ content in grains after harvest followed by $S_{4}-100$ per cent RDF through NPK with Iron + Zinc foliar applications and $S_{5}-100 \%$ RDF through FYM with Iron + Zinc foliar applications. All these parameters were observed lowest in the application of $S_{2}-100 \%$ RDF through FYM. Yuan et al. (2012) reported that grain yield, protein content and total amino acid was im- 
proved due to $\mathrm{Fe}$-amino acid and $0.5 \% \mathrm{ZnSO}_{4}$ spraying in rice grain. Shinde et al. (2014) recorded that highest values of protein per cent and protein yield of maize were recorded with application of $100 \% \mathrm{RDF}+10 \mathrm{t}$ FYM/ha. Similar findings were reported by Verma et al. (2012). Application of cattle manure + NPK significantly increased $\mathrm{Zn}$ concentration in corn grain over NPK (Manzeke et al. 2012). Soil amendment with small amounts of micronutrients has been suggested as a sustainable strategy to increase yields and nutritional quality of staple crops such as maize, rice, cassava, sorghum, millet, banana and sweet potato (Vanlauwe et al., 2015; Voortman and Bindraban, 2015; Manzeke et al., 2012). The Bioavailability of $\mathrm{Zn}$ in maize grains and stover was significantly increased by addition of organic manures and $\mathrm{Zn}$ fertilization. The results showed that a significant amount of $\mathrm{Fe}$ and $\mathrm{Zn}$ content persisted in maize grains when it was applied during the reproductive stage. The present results are in line with Tejada et al. (2006); Zhang et al. (2013); Patil et al. (2017) and Sadiq et al. (2018) who found that bioavailability of $\mathrm{Zn}$ in maize grains and stover was significantly increased by the addition of organic manures and $\mathrm{Zn}$ fertilization.Iron and Zinc foliar sprays were effective in $\mathrm{Zn}$ accumulation in grains (Augustine and Kalyanasundaram, 2020c).

\section{Conclusion}

The results of the present study showed that maize grown under irrigated condition in North eastern zone was highly responsive to agronomic biofortification. Since the nutrient levels by soil application offered no significant growth, yield, nutrient or quality advantages over the foliar applications, we concluded and recommended the nutrient levels of $\mathrm{Fe}$ and $\mathrm{Zn}$ foliar applications and 50 per cent RDF through NPK and 50 per cent RDF through FYM in the soil to hasten maize growth, productivity, yield attributes, nutrient uptake and quality. Such a combined long term approach may become a potential nutritional source for human and cattle populations. However, $\mathrm{Zn}$ and $\mathrm{Fe}$ foliar application at the reproductive stage have yielded a significantly higher content of $\mathrm{Zn}$ and $\mathrm{Fe}$ in maize grains besides improving other quality parameters. Thus integration of organic and inorganic fertilizers along with $\mathrm{Fe}$ and $\mathrm{Zn}$ foliar applications proved their efficiency to the reduction in inorganic fertilizer and with enhanced quality improvement. Experimental results concluded that the agronomic biofortification (integrated nutrient management with $\mathrm{Fe}$ and $\mathrm{Zn}$ foliar applications) practices can boost yields, nutrient uptake and maize quality by promoting in the North-eastern climatic zones of Tamil Nadu State.

\section{ACKNOWLEDGEMENTS}

The authors are thankful to the Professor and Head, Department of Agronomy, Faculty of Agriculture, Annamalai University for their advice and guidance during the research studies.

\section{Conflict of interest}

The authors declare that they have no conflict of interest.

\section{REFERENCES}

1. Agricultural Statistics at Glance (2019). Directorate of Economics and Statistics, Ministry of Agriculture, Government of India, New Delhi, 2019.

2. Agyenium, S.B., J.Zickermann and M. Kornoohrens (2006). Poultry manure effect on growth and yield of maize. West Africa J. Appl. Ecol., 9, 1-11.

3. Alloway, B.J. (2009). Soil factors associated with Zn deficiency in crops and humans. Environ. Geochem. Health, 31, 537-548.

4. Amanat, A. A. (1998). Effect of variable rates of nitrogen and phosphorus on growth and yield of maize. M.Sc., Thesis, Department of Agronomy, University of Agriculture, Faisalabad - Pakistan.

5. Amanullah, M.M. (1997). Effect of intercropping fertilizer levels and organic manures on the growth and yield of cassava (Manihot escluenta crantz). Ph.D. Thesis, TNAU, Coimbatore.

6. Augustine, R and Kalyanasundaram, D. (2020a). Agronomic biofortification through micronutrient management in maize: A review. Journal of Applied and Natural Science, 12(3), 430-437.

7. Augustine, R and Kalyanasundaram,D. (2020b). Agronomic biofortification of food crops with micronutrients. Plant Archives, 20(2), 1383-1387.

8. Augustine, R and Kalyanasundaram, D. (2020c). Perspectives on enhancing value of Agronomic biofortification in maize. Journal of Plant Development Science, 12(7), 383388.

9. Auwal Tukur Wailare and Amit Kesarwani (2017). Effect of Integrated Nutrient Management on Growth and Yield parameters of Maize (Zea mays I.) As well as Soil Physico -chemical Properties. Biomed J. Sci \& Tech Res., 1(2), 16.

10. Ayoola, O.T. and E.A. Makinde. (2009). Maize growth, yield and soil nutrient changes with $\mathrm{N}$-enriched organic fertilizers. African Journal of food, agriculture, nutrition and development, 9(1), 580-592.

11. Binoy Chhetri and A. C. Sinha (2017). Growth and development of maize (Zea mays L.) in response to different moisture conservation and Agronomic Biofortification under rainfed condition. Journal of Pharmacognosy and Phytochemistry, 6(6), 1696-1701.

12. Cakmak, I. (2008). Enrichment of cereal grains with zinc: Agronomic or genetic biofortification? Plant Soil, 302, 117.

13. Cakmak, I., Pfeiffer, W.H., McClafferty, B. (2010). Biofortification of durum wheat with zinc and iron. Cereal Chem., 
87(1), 10-20.

14. Chakraborti, M., Prasanna, B.M., Hossain, F., Singh, A.M. and Guleria, S.K. (2009). Genetic evaluation of kenel Fe and $\mathrm{Zn}$ concentrations and yield performance of selected maize (Zea mays L.) genotypes. Range Management and Agro-forestry, 30, 109-114.

15. Garcia-Bannelos, M.L., Sida-Arreola, J.P., Sanches, E. 2014. Biofortification - promising approach to increasing the content of iron and zinc in staple food crops. J. Elem., 19 (3), 865-888.

16. Gomez, K.A. and A.A. Gomez (1984). Statistical procedure for agricultural research. II edn. John Wiley and Sons, New York, 680p.

17. Hythum, M. S. And Nasser, K. B. (2012). Importance of Micronutrients and its Application methods for Improving Maize (Zea Mays L.) Yield Grown in Clayey Soil. American Eurasian J. Agric Environ Sci., 12(7), 954-959.

18. Kalyanasundaram. D and R. Augustine (2020). Production and Economics of Hybrid Maize (Zea mays L.) under Integrated Nutrient Management Practices. Agricultural Science Digest, D-5242 :1-7 DOI: 10.18805/ag.D-5242

19. Kalyanasundaram. D., R. Augustine and S. Harini Sri (2020). Integrated Nutrient Management in Hybrid Maize (Zea mays L.). Journal of Development Sciences, 12(8), 493-496.

20. Karan Verma, A.D. Bindra, Janardan Singh, S.C. Negi, Naveen Datt, Usha Rana and Sandeep Manuja, (2018) Int. Jr. Pure App. Bio sci., 6(3), 282-301.

21. Kolawale Edomwonyi and Samson Uduzei Remison (2009). Growth and Yield of Maize as Influenced by sowing date and Poultry Manure Application. Not. Bot. Hort. Agrobot. Cluj., 37(1), 199-203.

22. Kutman, U.B., Yildiz, B. and Cakmak, I. (2011a). Improved nitrogen status enhances zinc and iron concentrations both in the whole grain and the endosperm fraction of wheat. J. Cereal Sci. 53, 118-125.

23. Kutman, U.B., Yildiz, B. and Cakmak, I. (2011b). Effect of nitrogen on uptake, remobilization and partitioning of $\mathrm{Zn}$ and Fe throughout the development of durum wheat. Plant Soil, 342, 149-164.

24. Lakshmanan, R., Prasad, R. and Jain, M.C. (2005). Yield and uptake of micronutrients by rice as influenced by duration of variety and nitrogen utilization. Arch. Agron. Soil Sci. 51,1-14.

25. Lawson, P.G., Daum, D., Czaudema, R., Meuser, H., Harling, J.W. (2015). Soil versus foliar iodine fertilization as a biofortification strategy for field-grown vegetables. Front. Plant Sci., 6, 450.

26. Manzeke, G.M., Mapfumo, P., Mtambanengwe, F., Chikowo, R., Tendayi, T., Cakmak, I. (2012). Soil fertility management effects on maize productivity and grain zinc content in smallholder farming systems of Zimbabwe. Plant Soil, 361, 57-69.

27. Marschner, P. and Zed Rengel. (2012). Marschner's mineral nutrition of higher plants. $3^{\text {rd }}$ Edition. Elsevier, 12, 315330.

28. Mohsin, A.U., Ahmad, A.U.H., Farooq, M. and Ullah, S. (2014). Influence of zinc application through seed treatment and foliar spray on growth, productivity and grain quality of hybrid maize. The journal of Animal \& Plant Sciences, 24, 1494-1503.

29. NCoMM (2017). special report on Maize, NCML, Septem- ber 2017

30. Nikhil Kumar and Salakinkop, SR. (2018). Agronomic Biofortification of Maize with Zinc and Iron Micronutrients. Modern Concepts \& Development in Agronomy, 1(5), 2-5

31. Okoroafor, I., Okelola, E., Edeh, O., Nemehute, V., Onu, C., Nwaneri, T. and Chinaka, G. (2013). Effect of organic manure on the growth and yield performance of maize in Ishiagu, Ebonyi State, Nigeria. IOSR J. Agric. Vet. Sci., 5, 28-31.

32. Ozturk, L., Yazici, M.A., Yucel, C., Torun, A., Cekic, C., Bagci, A., Ozkan, H., Braun, H.J., Sayers, Z. and Cakmak, I. (2006). Concentration and localization of zinc during seed development and germination in wheat. Physiol. Plant, 128,144-152.

33. Pandey, KK., Awasthi, A. 2014. Integrated nutrient management in the maize (Zea mays L.) yield and soil properties. Internat. Journal of Agricultural Sciences, 10(1), 244246.

34. Patil, S., Girijesh, G., Nandini, K., Kumar, K., Pradeep, L. and Kumar, TR. (2017). Effect of zinc application through soil and foliar means on bio-fortification of zinc in rainfed maize (Zea mays L.). Int. J. Pure Appl. Biol. Sci. 5, 246253.

35. Phattarakul, N.., Rerkasem, B., Li, I. J., Wu, L.H., Zou, C.Q., Ram, H., Sohu, V.S., Kang, B.S., Surek, H., Kalayci, M., Yazici, A., Zhang, F.S., Cakmak, I. (2012). Biofortification of rice grain withzinc through zinc fertilization in different countries. Plant Soil, 361, 131-141.

36. Pooniya, V. and Shivay, YS. (2013). Enrichment of Basmati rice grain and Straw with Zinc and nitrogen through ferti-fortification and summer green manuring under IndoGangetic plains of India. Journal of Plant Nutrition, 36(1), 91-117.

37. Priya, S., Kaushik, M.K., Sharma, S.K., and Priyanka, K. (2014). Impact of integrated nutrient management on productivity of maize (Zea mays L.) Annals of Biology, 30 (1), 106-108.

38. Rajesh Ranjan Kumar, Neeraj Kumar, Jang Bahadur Rana and Kedar Nath Rai. (2018). Effect of Integrated Nutrient Management on yield of maize crop under rainfed condition in eastern part of uttarpradesh, India. Int.J.Curr.Microbiol.App.Sci., 7(9), 21-34.

39. Rahman, M.H., Islam, M.R., Jahiruddin, M., Puteh, A.B. and Mondal, M.M.A. (2013). Influence of Organic Matter on Nitrogen Mineralization Pattern in Soils under Different Moisture Regimes. International Journal of Agriculture and Biology, 15, 55-61.

40. Ravi, N., Basavarajappa, R., Chandrashekar, CP., Harlapur, SI. and Hosamani MH. (2012). Effect of Integrated Nutrient Management on Growth and Yield of Quality Protein Maize. Karnataka J. Agri Sci., 25(3), 395-396.

41. Roman Nissar, R. Zahida, R.H. Kanth, Ganai Manzoor, Raheel Shafeeq, H. Ashaq, R. Waseem, Raies A Bhat, M. Anwar Bhat and Sheikh Tahir. (2019). Agronomic Biofortification of major cereals with zinc and iron - A review. Agricultural reviews, 40(1), 21-28.

42. Sadiq Naveed, Abdur Rehim, Muhammad Imran, Muhammad Amjad Bashir, Muhammad Faraz Anwar and Fiaz Ahmad. (2018). Organic manures: an efficient move towards maize grain. International Journal of Recycling of Organic Waste in Agriculture, 7, 189-197.

43. Saleem, I., Javid, S., Bibi, F., Ehsan, S., Niaz, A. and Ah- 
mad, Z.A. (2016). Biofortification of maize grain with zinc and iron by using fertilizing approach. Journal of Agriculture and Ecology Research International, 7(4), 1-6.

44. Shahzad, Z., Rouached, H., Rakha, A. (2014). Combating mineral malnutrition through iron and zinc biofortification of cereals. Compr. Rev. Food Sci. Food Saf., 13(3), 329346.

45. Shi, R., Zhnag, Y., Chen, X., Sun, Q., Zhang, F., Romheld, V., Zou, C. (2010). Influence of long-term nitrogen fertilization on micronutrient density in grain of winter wheat (Triticum aestivum I.,), J. Cereal Sci., 51 (1), 165170.

46. Shinde, SA., Patange, MJ. and Dhage, SJ. (2014). Influence of irrigation schedules and integrated nutrient management on growth, yield and quality of rabi maize (Zea mays L.). International Journal of Current Microbiological Applied Sciences, 3(12), 828-832.

47. Shivay, Y.S. and Prasad, R. (2012). Zinc coated urea improves productivity and quality of basmatic rice (oryza sativa) under zinc stress condition. Journal of Plant Nutrition, 35, 928-951.

48. Sindhi, SJ., JD. Thanki and LJ. Desai. (2018). A review on integrated nutrient management (INM) approach for maize. Journal of Pharmacognosy and Phytochemistry, 7 (4), 3266-3269.

49. Singh, JP., Dahiya, DJ. and Vinod, K. (1995). Effect of nitrogen and iron supply on growth and nutrient uptake of maize on sandy soil. Crop Res., 10(3), 271-276.

50. Tasneem Khaliq, Tariqmahmod, Javed Kamal and Amir Masod. (2004). Effectiveness of farmyard manure, Poultry manure and nitrogen for corn (Zea mays L.) productivity. International Journal of Agriculture and Biology, 6(2), 260263.

51. Tejada, M., Hernandez, M.T. and Garcia, C. (2006). Application of two organic ammendments on soil restoration: effects on the soil biological properties. J. Environ Qual., 35, 1010-1017.

52. Tetarwal JP, Ram B. Meena DS. (2011). Effect of integrated nutrient management on productivity, profitability, nutrient uptake and soil fertility in rainfed maize (Zea mays). Indian Journal of Agronomy, 56(4), 373-376.

53. Vanlauwe, B., Descheemaeker, K., Giller, K.E., Huising, J., Mercks, R., Nziguheba, G., Wendt, J. and Zingore, S. (2015). Integrated soil fertility management in Sub-Saharan
Africa: Unravelling local adaptation. SOIL, 1, 491-508.

54. Verma NK, Pandey BK, Singh and UP. (2012). Effect of sowing dates in relation to integrated nitrogen management on growth, yield and quality of rabi maize (Zea Mays L.). Journal of Animals and Plant Sciences, 22(2), 324-329.

55. Voortman, R., Bindraban, P.S. (2015). Beyond N and P: Toward a land resource ecology perspective and impactful fertilizer interventions in sub-Saharan Africa. VFRC Report 2015/1. Virtual Fertilizer Research Centre, Washington, DC

56. White and Broadley (2011). Physiological Limits to Zinc Biofortification of Edible Crops. Front. Plant Sci., 2, 80.

57. Yashbir Singh Shivay and Rajendra Prasad. (2014). Effect of source and methods of zinc application on corn productivity, nitrogen and zinc concentrations and uptake by high quality protein corn (Zea mays). Egyptian Journal of Biology, 16, 72-78.

58. Yilmaz, A., H. Ekiz, B. Torun, I. Gultekin, S. Karanlik, S.A. Bagci, and I. Cakmak. (2007). Effect of different zinc application methods on grain yield and zinc concentration in wheat grown on zinc-deficient calcareous soils in Central Anatolia. J. Plant Nutr., 20, 461-471.

59. Yuan, L., Wu, L., Yang, C. and Lv.Q. (2012). Effects of iron and zinc foliar application on rice plants and their grain accumulation and grain nutritional quality. Journal of Science of Food and Agriculture, 93, 254-261.

60. Zerihun, A., Sharma J.J., Nigussie D. and Fred K. (2013). The effect of integrated organic and inorganic fertilizer rates on performances of soybean and maize component crops of a soyabean/maize mixture at Bako, Western Ethiopia: Academic Journals.

61. Zhang, Y.Q., Shi, R.L., Karim, M.R., Zhang, F.S. and Zou, C.Q. (2010). Iron and zinc concentrations in grain and flour of winter wheat as affected by foliar application. Journal of Agricultural and Food Chemistry, 58, 12268-12274.

62. Zhang, Y.Q., Pang, LL., Yan, P., Liu, DY., Zhang, W., Yost, R., Zhang, FS. and Zou, CQ. (2013). Zinc fertilizer placement affects zinc content in maize plant. Plant Soil, $372,81-92$.

63. Zhu, C., Naqvi, S., Gomez-Galera, S., Pelacho, AM., Capell, T. and Christou, P. (2007). Transgenic strategies for the nutritional enhancement of plants. Trends Plant Sci., $12,548-55$. 